\title{
Review \\ ALISKIREN, OBAT ANTIHIPERTENSI BARU DENGAN MEKANISME PENGHAMBAT RENIN
}

\author{
Diana Holidah \\ Bagian Farmasi Klinik dan Komunitas, Fakultas Farmasi Universitas Jember, Jember, Jawa Timur \\ e-mail:dien_holy@yahoo.com
}

\begin{abstract}
Hypertension is a chronic disease with a prevalence reaching 1 billion people around the world. Hypertension is the major treatable risk factor for cardiovascular disease, which remains the leading cause of death in the industrialized world. Despite the risks associated with the condition, the majority of patients with hypertension across the world do not have their blood pressure (BP) controlled to recommended target levels. RAAS is a main target, although, in total inhibition of RAAS can not be obtained with ACEI and ARB class of drugs because of the feedback mechanism. As a solution, we could inhibit the early stages of the mechanism, that is renin. Previous studies have indicated that the renin inhibitor class of drugs effective as antihypertensive and well tolerated, both as monotherapy and in combination with other drugs. Based on researched to aliskiren and the success of antihypertensive drug class of ACEI and ARB in reducing morbidity and mortality in patients with hypertension, it is rational if the expected drug classes like renin inhibitor aliskiren would provide the same benefits. Whether the benefits are equal, larger or even smaller than another RAAS inhibitor, we needed long research to find supporting data.
\end{abstract}

Key word: Aliskiren, hypertension, renin

\begin{abstract}
ABSTRAK
Hipertensi merupakan salah satu penyakit kronis dengan prevalensi mencapai 1 milyar jiwa di seluruh dunia. Hipertensi yang menginduksi penyakit kardiovaskular merupakan penyebab utama kematian di dunia. Pengaturan tekanan darah hingga optimal masih sulit untuk dicapai di semua Negara. RAAS merupakan target utama, walaupun begitu, penghambatan RAAS secara total tidak dapat diperoleh dengan penggunaan obat golongan ACEI dan ARB karena adanya mekanisme umpan balik. Sebagai solusinya, dapat dilakukan penghambatan pada tahap awal dari mekanisme tersebut yaitu pada renin. Penelitian sebelumnya sudah mengindikasikan bahwa obat golongan renin inhibitor efektif sebagai antihipertensi dan dapat ditoleransi dengan baik, baik sebagai monoterapi maupun dikombinasi dengan obat lain. Berdasarkan penelitian yang sudah dilakukan terhadap aliskiren serta keberhasilan obat antihipertensi golongan ACEI dan ARB dalam menurunkan angka morbiditas dan mortalitas pada penderita hipertensi, maka sangat rasional jika diharapkan obat golongan renin inhibitor seperti aliskiren akan memberikan manfaat yang sama. Apakah manfaat tersebut sama, lebih besar atau justru lebih kecil daripada yang ditunjukkan oleh inhibitor RAAS yang lain, maka diperlukan penelitian lain yang panjang untuk mencari data pendukung.
\end{abstract}

Kata kunci: Aliskiren, hipertensi, rennin 


\section{PENDAHULUAN}

Hipertensi atau tekanan darah tinggi merupakan salah satu penyakit kronis yang banyak ditemukan di Indonesia, bahkan juga di seluruh dunia. Prevalensi hipertensi di seluruh dunia mencapai 1 milyar jiwa dan terdapat sekitar 7,1 juta jiwa penderita yang meninggal setiap tahunnya.

Pengobatan yang efektif dapat menjaga agar tekanan darah berada dalam keadaan normal selama hampir 50 tahun. Dalam beberapa dekade, pengobatan hipertensi dapat menurunkan resiko terjadinya stroke dan serangan jantung. Tetapi, pada dekade terakhir terjadi peningkatan kejadian gagal jantung kronis dan ESRD (End Stage Renal Disease). Ada beberapa faktor penyebab diantaranya adalah kurang optimalnya strategi pencegahan dan pengobatan hipertensi, sehingga perlu penelitian lebih lanjut untuk menemukan obat baru yang lebih baik untuk penderita hipertensi esensial [1].

Dalam strategi pengobatan hipertensi salah satu targetnya adalah sistem renin angiotensin aldosteron (RAAS). RAAS memegang peranan kunci dalam regulasi tekanan darah, bekerja terutama melalui efek pada hormon angiotensin II. Aktivitas RAAS yang berlebih adalah penyebab utama dari beberapa keadaan patologi karena AngII akan meningkatkan tekanan darah dan menyebabkan terjadinya kerusakan pada organ. Dalam perkembangan selanjutnya telah ditemukan beberapa senyawa yang mempunyai efek sebagai renin inhibitor dan memiliki bioavailabilitas yang cukup baik sehingga dapat dikembangkan sebagai obat. Salah satu senyawa yang banyak diteliti adalah aliskiren [1].

\section{HIPERTENSI}

\section{Definisi}

Tekanan darah tinggi atau hipertensi adalah kondisi medis di mana terjadi peningkatan tekanan darah secara kronis (dalam jangka waktu lama). Penderita yang mempunyai sekurang-kurangnya tiga bacaan tekanan darah yang melebihi $140 / 90 \mathrm{mmHg}$ saat istirahat diperkirakan mempunyai keadaan darah tinggi. Tekanan darah yang selalu tinggi adalah salah satu faktor resiko untuk stroke, serangan jantung, gagal jantung dan aneurisma arterial, dan merupakan penyebab utama gagal jantung kronis.

Pada pemeriksaan tekanan darah akan didapat dua angka. Angka yang lebih tinggi diperoleh pada saat jantung berkontraksi (sistolik), angka yang lebih rendah diperoleh pada saat jantung berelaksasi (diastolik). Tekanan darah kurang dari 120/80 mmHg didefinisikan sebagai "normal". Pada tekanan darah tinggi, biasanya terjadi kenaikan tekanan sistolik dan diastolik. Hipertensi biasanya terjadi pada tekanan darah 140/90 $\mathrm{mmHg}$ atau ke atas, diukur di kedua lengan tiga kali dalam jangka beberapa minggu.

Pada hipertensi sistolik terisolasi, tekanan sistolik mencapai $140 \mathrm{mmHg}$ atau lebih, tetapi tekanan diastolik kurang dari 90 $\mathrm{mmHg}$ dan tekanan diastolik masih dalam kisaran normal.

Hipertensi ini sering ditemukan pada usia lanjut. Sejalan dengan bertambahnya usia, hampir setiap orang mengalami kenaikan tekanan darah; tekanan sistolik terus meningkat sampai usia 80 tahun dan tekanan diastolik terus meningkat sampai usia 55-60 tahun, kemudian berkurang secara perlahan atau bahkan menurun drastis. Dalam pasien dengan diabetes mellitus atau penyakit ginjal, penelitian 
telah menunjukkan bahwa tekanan darah di atas 130/80 $\mathrm{mmHg}$ harus dianggap sebagai faktor resiko dan sebaiknya diberikan perawatan [2].

\section{Pengaturan tekanan darah}

Tekanan darah ditentukan oleh dua faktor utama, yaitu curah jantung (cardiac output) dan resistensi vaskular perifer (peripheral vascular resistance).

Curah jantung merupakan hasil kali antara frekwensi denyut jantung dengan isi sekuncup (stroke volume), sedangkan isi sekuncup ditentukan oleh aliran balik vena (venous return) dan kekuatan kontraksi miokard.

\section{Klasifikasi}

Tabel 1. Klasifikasi Tekanan Darah Pada Dewasa

\begin{tabular}{ccc}
\hline Kategori & Tekanan Darah Sistolik & Tekanan Darah Diastolik \\
\hline Normal & $<120 \mathrm{mmHg}$ & (dan) $<80 \mathrm{mmHg}$ \\
Pre-hipertensi & $120-139 \mathrm{mmHg}$ & (atau) $80-89 \mathrm{mmHg}$ \\
Stadium 1 & $140-159 \mathrm{mmHg}$ & (atau) $90-99 \mathrm{mmHg}$ \\
Stadium 2 & $\geq 160 \mathrm{mmHg}$ & (atau) $\geq 100 \mathrm{mmHg}$ \\
\hline
\end{tabular}

Resistensi perifer ditentukan oleh tonus otot polos pembuluh darah, elastisitas dinding pembuluh darah dan viskositas darah. Semua parameter diatas dipengaruhi oleh beberapa faktor antara lain sistem saraf simpatis dan parasimpatis, sistem renin-angiotensin-aldosteron (RAAS) dan faktor lokal berupa bahan-bahan vasoaktif yang diproduksi oleh sel endotel pembuluh darah.

Sistem saraf simpatis bersifat presif, yaitu cenderung meningkatkan tekanan darah dengan meningkatkan frekwensi denyut jantung, memperkuat kontraktilitas miokard dan meningkatkan resistensi pembuluh darah. Sistem parasimpatis bersifat depresif, yaitu menurunkan tekanan darah karena menurunkan frekwensi denyut jantung. RAAS juga bersifat presif berdasarkan efek vasokontriksi angiotensin II dan perangsangan aldosteron yang menyebabkan retensi air dan natrium di ginjal sehingga meningkatkan volume darah. Selain itu terdapat sinergisme antara sistem simpatis dan RAAS yang saling memperkuat efek masing-masing.
Sel endotel pembuluh darah memproduksi berbagai bahan vasoaktif yang sebagian bersifat vasokontriktor seperti endotelin, tromboksan A2 dan angiotensin II lokal, dan sebagian lagi bersifat vasodilator seperti endothelium-derived relaxing factor (EDRF) yang dikenal juga dengan nitric oxide (NO) dan prostasiklin (PGI2). Selain itu, jantung, terutama atrium kanan memproduksi hormon yang disebut atriopeptin (atrial natriuretic peptide, ANP) yang bersifat diuretik, natriuretik dan vasodilator yang cenderung menurunkan tekanan darah [3].

Meningkatnya tekanan darah di dalam arteri bisa terjadi melalui beberapa cara:

1. Jantung memompa lebih kuat sehingga mengalirkan lebih banyak cairan pada setiap detiknya

2. Arteri besar kehilangan kelenturannya dan menjadi kaku, sehingga mereka tidak dapat mengembang pada saat jantung memompa darah melalui arteri tersebut. Karena itu darah pada setiap denyut jantung dipaksa untuk melalui pembuluh yang sempit daripada biasanya dan menyebabkan naiknya 
tekanan. Inilah yang terjadi pada usia lanjut, dimana dinding arterinya telah menebal dan kaku karena arteriosklerosis. Dengan cara yang sama, tekanan darah juga meningkat pada saat terjadi "vasokonstriksi", yaitu jika arteri kecil (arteriola) untuk sementara waktu mengkerut karena perangsangan saraf atau hormon di dalam darah.

3. Bertambahnya cairan dalam sirkulasi bisa menyebabkan meningkatnya tekanan darah. Hal ini terjadi jika terdapat kelainan fungsi ginjal sehingga tidak mampu membuang sejumlah garam dan air dari dalam tubuh. Volume darah dalam tubuh meningkat, sehingga tekanan darah juga meningkat.

Sebaliknya, jika aktivitas memompa jantung berkurang, arteri mengalami pelebaran, banyak cairan keluar dari sirkulasi maka tekanan darah akan menurun atau menjadi lebih kecil. Penyesuaian terhadap faktor-faktor tersebut dilaksanakan oleh perubahan di dalam fungsi ginjal dan sistem saraf otonom (bagian dari sistem saraf yang mengatur berbagai fungsi tubuh secara otomatis).

\section{Perubahan fungsi ginjal}

Ginjal mengendalikan tekanan darah melalui beberapa cara:

a. Jika tekanan darah meningkat, ginjal akan menambah pengeluaran garam dan air, yang akan menyebabkan berkurangnya volume darah dan mengembalikan tekanan darah ke normal

b. Jika tekanan darah menurun, ginjal akan mengurangi pembuangan garam dan air, sehingga volume darah bertambah dan tekanan darah kembali ke normal

c. Ginjal juga bisa meningkatkan tekanan darah dengan menghasilkan enzim yang disebut renin, yang memicu pembentukan hormon angiotensi, yang selanjutnya akan memicu pelepasan hormon aldosteron

Ginjal merupakan organ penting dalam mengendalikan tekanan darah; karena itu berbagai penyakit dan kelainan pda ginjal bisa menyebabkan terjadinya tekanan darah tinggi. Penyempitan arteri yang menuju ke salah satu ginjal (stenosis arteri renalis) bisa menyebabkan hipertensi. Peradangan dan cedera pada salah satu atau kedua ginjal juga bisa menyebabkan naiknya tekanan darah.

\section{Sitem saraf otonom}

Sistem saraf simpatis merupakan bagian dari sistem saraf otonom, yang untuk sementara waktu akan:

a. meningkatkan tekanan darah selama respon fight-or-flight (reaksi fisik tubuh terhadap ancaman dari luar).

b. meningkatkan kecepatan dan kekuatan denyut jantung; juga mempersempit sebagian besar arteriola, tetapi memperlebar arteriola di daerah tertentu (misalnya otot rangka, yang memerlukan pasokan darah yang lebih banyak)

c. mengurangi pembuangan air dan garam oleh ginjal, sehingga akan meningkatkan volume darah dalam tubuh

d. melepaskan hormon epinefrin (adrenalin) dan norepinefrin (noradrenalin), yang merangsang jantung dan pembuluh darah.

\section{Gejala}

Pada sebagian besar penderita, hipertensi tidak menimbulkan gejala; meskipun secara tidak sengaja beberapa gejala terjadi bersamaan dan dipercaya berhubungan dengan tekanan darah tinggi (padahal sesungguhnya tidak). Gejala yang 
dimaksud adalah sakit kepala, perdarahan dari hidung, pusing, wajah kemerahan dan kelelahan; yang bisa saja terjadi baik pada penderita hipertensi, maupun pada seseorang dengan tekanan darah yang normal.

Jika hipertensinya berat atau menahun dan tidak diobati, bisa timbul gejala sakit kepala, kelelahan, mual, muntah, sesak nafas, gelisah, pandangan menjadi kabur yang terjadi karena adanya kerusakan pada otak, mata, jantung dan ginjal. Kadang penderita hipertensi berat mengalami penurunan kesadaran dan bahkan koma karena terjadi pembengkakan otak. Keadaan ini disebut ensefalopati hipertensif, yang memerlukan penanganan segera.

\section{Penyebab hipertensi}

Hipertensi berdasarkan penyebabnya dibagi menjadi 2 jenis :

1. Hipertensi primer atau esensial adalah hipertensi yang tidak / belum diketahui penyebabnya (terdapat pada kurang lebih $90 \%$ dari seluruh hipertensi).

2. Hipertensi sekunder adalah hipertensi yang disebabkan/ sebagai akibat dari adanya penyakit lain.

Hipertensi primer kemungkinan memiliki banyak penyebab; beberapa perubahan pada jantung dan pembuluh darah kemungkinan bersama-sama menyebabkan meningkatnya tekanan darah. Jika penyebabnya diketahui, maka disebut hipertensi sekunder. Pada sekitar 5-10\% penderita hipertensi, penyebabnya adalah penyakit ginjal. Pada sekitar 1-2\%, penyebabnya adalah kelainan hormonal atau pemakaian obat tertentu (misalnya pil $\mathrm{KB}$ ). Penyebab hipertensi lainnya yang jarang adalah feokromositoma, yaitu tumor pada kelenjar adrenal yang menghasilkan hormon epinefrin (adrenalin) atau norepinefrin (noradrenalin). Kegemukan (obesitas), gaya hidup yang tidak aktif (malas berolah raga), stres, alkohol atau garam dalam makanan; bisa memicu terjadinya hipertensi pada orang-orang memiliki kepekaan yang diturunkan. Stres cenderung menyebabkan kenaikan tekanan darah untuk sementara waktu, jika stres telah berlalu, maka tekanan darah biasanya akan kembali normal.

\section{TUJUAN DAN STRATEGI PENGOBATAN HIPERTENSI}

Tujuan pengobatan hipertensi adalah untuk menurunkan angka morbiditas dan mortalitas kardiovaskular. Penurunan tekanan sistolik harus menjadi perhatian utama, karena pada umumnya tekanan diastolik akan terkontrol bersamaan dengan terkontrolnya tekanan sistolik. Target tekanan darah bila tanpa kelainan penyerta adalah <140/90 $\mathrm{mmHg}$, sedangkan pada pasien dengan diabetes mellitus atau kelainan ginjal, tekanan darah harus diturunkan di bawah 130/80 mmHg. Terdapat hubungan yang nyata antara tekanan darah dengan keadaan kardiovaskular. Untuk individu berusia diatas 40 tahun, tiap peningkatan tekanan darah sebesar 20/10 mmHg meningkatkan risiko kejadian kardiovaskular dua kali lipat. Hal ini berlaku pada rentang tekanan darah 115/75 sampai 185/115 mmHg.

Strategi pengobatan hipertensi harus dimulai dengan perubahan gaya hidup berupa diet rendah garam, berhenti merokok, mengurangi konsumsi alcohol, aktivitas fisik yang teratur dan penurunan berat badan bagi pasien dengan berat badan lebih. Selain dapat menurunkan tekanan darah, perubahan gaya hidup juga terbukti meningkatkan efektivitas obat antihipertensi dan menurunkan resiko kardiovaskular [3]. 


\section{OBAT-OBAT ANTIHIPERTENSI}

Pemilihan obat dalam terapi hipertensi tergantung pada derajat peningkatan tekanan darah dan keberadaan indikasi penyakit lain yang menyertai (compelling indication). Ada lima golongan obat merupakan agen primer atau first line therapy untuk hipertensi berdasarkan pada data kerusakan organ target atau tingkat morbiditas dan mortalitas kardiovaskuler, kelima golongan obat tersebut, adalah:

a. Diuretik

b. Beta blocker

c. Angiotensin converting enzim inhibitor (ACEI)

d. Angiotensin II receptor blocker (ARB)

e. Calcium channel blocker (CCB)

Selain itu, juga ada beberapa golongan obat yaitu $\alpha$ blocker, $\alpha 2$-agonis sentral, inhibitor adrenergic, dan vasodilator yang merupakan second line therapy yang merupakan alternatif yang dapat digunakan penderita setelah mendapat obat pilihan pertama (4). Dalam artikel ini akan dibahas lebih jauh mengenai obat-obat yang bekerja pada RAAS serta obat baru yang juga bekerja pada sistem ini yaitu Aliskiren.

\section{RENIN-ANGIOTENSIN-ALDOSTERON SYSTEM (RAAS)}

RAAS berperan dalam pengaturan tekanan darah dan volume cairan tubuh. Sistem ini tidak terlalu aktif pada individu dengan volume darah dan kadar natrium normal, tapi sangat penting bila ada penurunan tekanan darah atau deplesi cairan atau garam. Reaksi pertama tubuh terhadap penurunan volume darah adalah peningkatan sekresi renin dari sel juktaglomeruler di arteriol aferen ginjal.

Renin adalah enzim proteolitik yang disintesis oleh sel-sel juktaglomeruler di ginjal dan merupakan penentu (rate limiting step) aktivitas RAAS. Sekresinya meningkat bila terjadi penurunan aliran darah ginjal (misalnya akibat penurunan tekanan darah, stenosis arteri renalis, gagal jantung, perdarahan dan dehidrasi), hiponatremia (akibat diet rendah garam) dan rangsangan adrenergik melalui reseptor $\beta 1$. Angiotensin adalah suatu $\alpha$ globulin yang disintesis dalam hati dan beredar dalam darah. Renin berfungsi mengubah angiotensinogen menjadi I (AngI), yang merupakan hormone yang belum aktif. Selanjutnya AngI akan diubah oleh angiotensin converting enzim (ACE) menjadi angiotensin II (AngII) yang memiliki efek vasokontriksi yang sangat kuat dan merangsang sekresi aldosteron dari korteks adrenal. ACE disintesis dalam sel-sel endotel seluruh sistem vaskular terutama dalam sistem kapiler paru-paru dan ginjal. Disamping mengubah AngI menjadi AngII, ACE juga berperan dalam degradasi bradikinin menjadi kinin non aktif. Bradikinin merupakan vasodilator yang poten yang bekerja dengan meningkatkan sintesis EDRF (endothelium derived relaxing factor) dan prostasiklin (PGI2) di sel-sel endotel vascular.

\section{Mekanisme Kerja Angiotensin II}

Angiotensin II adalah suatu oktapeptida yang merupakan komponen aktif dalam RAAS dan bekerja pada system kardiovaskuler dan neuro-endokrin. Dikenal dua jenis reseptor angiotensin II, yaitu reseptor AT1 dan AT2, tapi yang paling berperan dalam efek AngII adalah reseptor AT1. Ikatan AngII pada reseptor AT1 akan mengaktifkan fosfolipase C (PLC). PLC selanjutnya mengubah fosfoinositol di fosfat (IP2) menjadi inositol trifosfat (IP3) dan diasil griserol (DAG). IP3 menyebabkan mobilisasi kalsium dari retikulum sarkoplasma ke sitoplasma sehingga terjadi peningkatan 
kalsium di sitoplasma. Hal ini menyebabkan depolarisasi membran sel dan terbukanya kanal kalsium. Selanjutnya terjadi influx massif kalsium ke dalam sel dan menyebabkan kontraksi sel otot polos vaskular (vasokontriksi). Efek ini merupakan mekanisme utama peningkatan tekanan darah oleh sistem renin angiotensin.

Pada sistem kardiovaskular, AngII menyebabkan vasokontriksi arteriol dan venula (efek pada arteriol lebih kuat) dan meningkatkan kekuatan kontraksi miokard. Pada sistem neuro endokrin terjadi stimulasi sekresi aldosteron dari korteks adrenal yang menyebabkan retensi air dan natrium serta ekskresi kalium di ginjal. Selain itu, di tingkat SSP, AngII menyebabkan stimulasi rasa haus dan peningkatan sekresi ADH (vasopressin), sehingga mempertinggi volume cairan dalam sirkulasi dan memperkuat efek vasokontriksi. AngII juga meningkatkan sekresi katekolamin dari ujung saraf simpatis dan menambah efek vasokontriksi dan stimulasi jantung. Semua ini akan berakibat peningkatan tekanan darah. Dalam jangka panjang AngII merangsang proliferasi sel otot polos pembuluh darah dan miokard, dan akan memfasilitasi proses aterosklerosis. AngII sendiri menyebabkan reaksi umpan balik negatif di ginjal yang mengurangi sekresi renin.

\section{Angiotensin Converting Enzim Inhibitor (ACEI)}

Kaptopril merupakan ACEI yang pertama kali ditemukan dan banyak digunakan di klinik untuk pengobatan hipertensi dan gagal jantung. Secara umum ACEI dibedakan menjadi dua kelompok, yaitu: 1) yang bekerja langsung, contohnya kaptopril dan lisinopril, 2). Prodrug, contohnya enalapril, kuinapril, perindopril, ramipil, silazapril dan lain-lain.
ACEI menghambat perubahan AngI menjadi AngII sehingga terjadi vasodilatasi dan penurunan sekresi aldosteron. Selain itu, degradasi bradikinin juga dihambat sehingga kadar bradikinin dalam darah meningkat dan berperan dalam efek vasodilatasi ACEI. Vasodilatasi secara langsung akan menurunkan tekanan darah, sedangkan berkurangnya aldosteron akan menyebabkan ekskresi air dan natrium serta retensi kalium.

\section{Angiotensin Receptor Blockers (ARB)}

Losartan merupakan prototipe obat golongan ARB yang bekerja selektif pada reseptor AT1. Pemberian obat ini akan menghambat semua efek AngII, seperti vasokontriksi, sekresi aldosteron, rangsangan saraf simpatis, efek sentral AngII (sekresi vasopressin, rangsangan haus), stimulasi jantung, efek renal serta efek jangka panjang berupa hipertrofi otot polos pembuluh darah dan miokard. Dengan kata lain, ARB menimbulkan efek yang mirip dengan pemberian ACEI, tapi karena tidak mempengaruhi metabolisme bradikinin maka obat ini dilaporkan tidak memiliki efek samping batuk kering dan angioedema seperti yang sering terjadi dengan ACEI (3).

\section{RENIN INHIBITOR}

RAAS memegang peranan kunci dalam regulasi tekanan darah, bekerja terutama melalui efek pada hormon angiotensin II. Aktivitas RAAS yang berlebih adalah penyebab utama dari beberapa keadaan patologi karena AngII akan meningkatkan tekanan darah dan menyebabkan terjadinya kerusakan pada organ. Obat yang sudah beredar, seperti ACEI dan ARBs memberikan jaminan keberhasilan terapi penyakit hipertensi, gagal jantung serta penyakit kardiovaskular lainnya. Walaupun begitu, ACEI dan ARBs hanya menekan 
sebagian RAAS, karena akan menstimulasi mekanisme kompensasi untuk meningkatkan aktivitas renin plasma yang dapat menyebabkan peningkatan kadar AngII $(5 ; 6)$.

Renin merupakan katalisator pertama dalam RAAS dan memiliki spesifisitas yang tinggi terhadap substratnya yaitu angiotensin. Inhibitor renin mempunyai potensi untuk mencegah terjadinya system kompleks hormonal pada awal aktivasinya sehingga memberikan efek samping yang rendah. Renin inhibitor bekerja dengan mencegah pembentukan AngI dan AngII maka akan memberikan profil terapi seperti gabungan ACEI dan ARBs. Penghambatan ACE akan menyebabkan peningkatan AngI, dimana kemudian ada kemungkinan untuk berubah menjadi AngII melalui jalur independen yang tidak dapat dihambat oleh ACEI. Selain itu, renin inhibitor juga tidak mempengaruhi metabolisme kinin sehingga tidak menyebabkan batuk kering atau edema angioneurotik, yang merupakan efek samping dari penggunaan ACEI. ARBs akan meningkatkan kadar, dan efek samping ini tidak akan terjadi jika menggunakan renin inhibitor. Sejumlah besar renin inhibitor telah berkembang selama 20 tahun terakhir, tetapi memiliki potensi dan bioavailabilitas yang rendah dan durasi kerja yang singkat jika diberikan per oral, sehingga senyawa tersebut secara klinis tidak berguna sebagai obat (5). Dalam perkembangan selanjutnya telah ditemukan beberapa senyawa yang mempunyai efek sebagai renin inhibitor dan memiliki bioavailabilitas yang cukup baik sehingga dapat dikembangkan sebagai obat. Salah satu senyawa yang banyak diteliti adalah aliskiren.

\section{ALISKIREN}

Aliskiren, $\quad 2(S), 4(S), 5(S), 7(S)-N-(2-$ carbamoyl-2-methylpropyl)-5-amino-4- hydroxy-2,7-diisopropyl-8-[4-meth oxy-3(3-methoxypropoxy) phenyl]-octanamid hemifumarate merupakan senyawa pertama dari golongan renin inhibitor yang efektif secara oral, merupakan senyawa non peptide dengan BM rendah dan digunakan untuk terapi pada hipertensi. Dirancang dari sebuah kombinasi teknik modeling molecular dan elusidasi struktur Kristal, aliskiren adalah inhibitor renin yang poten dan spesifik secara in vitro (IC $=0,6$ $\mathrm{nmol} / \mathrm{L})$.

Pemberian aliskiren per oral pada marmoset yang kehilangan sodium menyebabkan terjadinya penghambatan sempurna dari renin dan terjadi penurunan tekanan darah arteri secara bertahap.

Penelitian pada hewan coba juga menunjukkan pemberian aliskiren mampu memperbaiki organ yang rusak akibat hipertensi (1). Pada manusia, pemberian aliskiren sekali sehari hingga dosis $640 \mathrm{mg}$ dapat ditoleransi dengan baik dan menyebabkan penghambatan RAAS pada relawan sehat.

Penelitian terbaru pada 226 pasien menunjukkan bahwa pemberian aliskiren $300 \mathrm{mg}$ perhari akan menurunkan tekanan darah dengan efikasi dan keamanan setara dengan pemberian losartan dua kali sehari.

Pada penelitian yang dilakukan oleh [5], aliskiren diberikan pada pasien penderita hipertensi ringan sampai sedang sekali sehari dengan dosis $150,300,600$ selama 8 minggu. Efek aliskiren dibandingkan dengan placebo dan Irbesartan. Hasil penelitian menunjukkan terapi oral aliskiren sekali sehari akan menurunkan tekanan darah secara efektif pada pasien hipertensi ringan sampai sedang. Aliskiren dosis $150 \mathrm{mg}$ memberikan efek anti hipertensi setara dengan irbesartan $150 \mathrm{mg}$ dan aliskiren dosis yang lebih besar 
menurunkan tekanan darah diastole lebih efektif daripada irbesartan $150 \mathrm{mg}$. Terapi sekali sehari dengan aliskiren 150, 300 dan $600 \mathrm{mg}$ akan menurunkan tekanan darah sistole dan diastole secara signifikan jika dibandingkan dengan placebo. Analisis statistik menyebutkan bahwa efek anti hipertensi aliskiren bersifat tergantung dosis hingga mencapai dosis $300 \mathrm{mg}$. Aliskiren $300 \mathrm{mg}$ menurunkan tekanan darah diastole dengan lebih efektif dan akan mencapai level yang lebih rendah jika dibandingkan dengan aliskiren dosis 150 mg. Hal tersebut mengindikasikan bahwa peningkatan dosis aliskiren dapat digunakan untuk menurunkan tekanan darah pasien yang tidak dapat dikontrol dengan aliskiren $150 \mathrm{mg}$. Tetapi tidak ada penurunan tekanan darah yang signifikan pada penggunaan aliskiren dosis $600 \mathrm{mg}$, sehingga plateu aliskiren terjadi pada dosis $300 \mathrm{mg}$. Pengukuran tekanan darah secara berkala juga mengindikasikan efek antihipertensif aliskiren selama 24 jam setelah pemberian. Hasil tersebut menegaskan bahwa aliskiren memberikan hasil penurunan tekanan darah yang lebih efektif setelah pemberian dosis oral sekali sehari (5). Pemberian aliskiren dosis 300 dan $600 \mathrm{mg}$ akan menghambat renin $>99 \%$ pada jam ke-5 setelah pemberian per oral dan hambatan masih $>95 \%$ pada jam ke24. Setelah 48 jam, penghambatan renin akan mencapai $>85 \%$ [7].

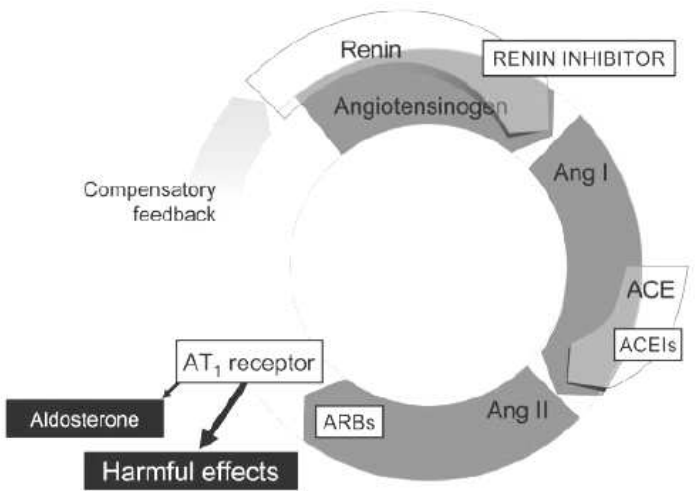

Gambar 1. Skema RAAS dan tempat kerja tiap golongan obat (1)

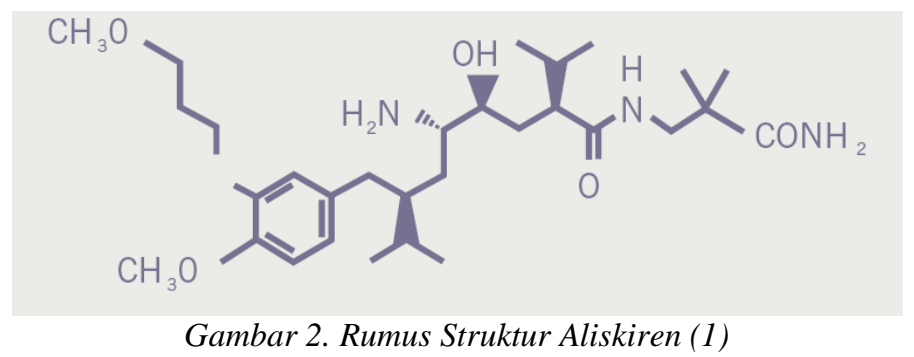

Terapi dengan aliskiren juga menunjukkan profil keamanan dan tolerabilitas yang baik. Pada semua dosis yang diteliti, pemberian aliskiren menyebabkan efek samping yang relatif kecil setara dengan yang teramati pada kelompok placebo dan irbesartan. Tolerabilitas aliskiren yang setara dengan placebo merupakan hasil yang penting secara klinis karena efek samping merupakan faktor yang sulit diterima pasien dalam terapi hipertensi.

Penelitian lain yang dilakukan oleh [8], pada pasien penderita hipertensi di jepang 
juga menunjukkan bahwa terapi menggunakan aliskiren dapat diterima dengan baik. Tingkat kejadian efek samping pada kelompok yang diterapi dengan aliskiren mencapai $53-55 \%$ setara dengan efek samping yang timbul pada kelompok placebo $(50 \%)$.

Penelitian lain dilakukan oleh [6] dengan subyek pasien hipertensi di jepang dan kaukasian. Tujuan penelitian ini untuk membandingkan profil farmakokinetika aliskiren setelah pemberian per oral pada subyek dengan ras yang berbeda, karena diketahui bahwa disposisi dan respon terhadap obat dapat berbeda antar etnik yang disebabkan variasi genetik pada enzim pemetabolisme obat.

Hasil penelitian menunjukkan profil farmakokinetika dan efek farmakodinamik aliskiren yang sebanding antara subyek orang jepang dan kaukasian. Walaupun nilai Cmax dan AUC setelah pemberian aliskiren secara oral maupun pada keadaan steady state sedikit lebih besar pada orang jepang dibandingkan kaukasian, hal ini diduga karena adanya perbedaan berat badan antara kedua kelompok tersebut. Rata-rata berat badan orang jepang $12 \%$ lebih rendah daripada kaukasian sehingga jumlah obat yang masuk dari dosis yang diberikan lebih besar pada subyek dengan berat badan lebih rendah. Walaupun begitu, perbedaan AUC kurang dari 20\% tidak memiliki makna klinis. Metabolisme aliskiren rendah sehingga variasi genetik pada enzim CYP 450 antar etnik tidak menyebabkan perbedaan disposisi. Nilai $\mathrm{t}_{1 / 2}$ aliskiren lebih dari 24 jam, hal ini menunjukkan bahwa aliskiren dapat diberikan sekali sehari dan dapat mengatur tekanan darah selama 24 jam sehingga dapat mencegah terjadinya kerusakan organ.
Untuk parameter farmakodinamik diamati nilai plasma renin concentration (PRC) dan plasma renin activity (PRA). Peningkatan nilai PRC yang diamati setelah pemberian aliskiren menunjukkan indicator dari penghambatan RAAS dan disebabkan oleh gangguan pada putaran balik dimana pada keadaan normal AngII akan menghambat pelepasan renin dari ginjal. Meskipun terjadi peningkatan PRC, aliskiren menghambat PRA selama 24 jam. Hal tersebut menunjukkan bahwa aliskiren adalah inhibitor renin oral yang sangat efektif dan mendukung penemuan sebelumnya bahwa peningkatan PRC tidak membahayakan kemampuan aliskiren untuk menghambat aktivitas renin. Kemampuan aliskiren untuk menghambat PRA memiliki relevansi klinis. Beberapa penelitian menunjukkan peningkatan kadar PRA berhubungan dengan kerusakan organ dan meningkatnya resiko terjadinya infark miokard pada pasien hipertensi [6].

Beberapa penelitian lain juga menunjukkan aliskiren dapat digunakan dalam terapi kombinasi dengan obat antihipertensi yang lain. Kombinasi aliskiren $150 \mathrm{mg}$ dan valsartan $160 \mathrm{mg}$ merupakan kombinasi yang direkomendasikan penggunaannya karena menyebabkan penurunan tekanan darah yang lebih besar jika dibandingkan dengan penggunaan aliskiren maupun valsartan tunggal dengan profil tolerabilitas yang setara [9]. Efek aliskiren akan meningkat dengan penambahan diuretic yaitu HCTZ. Kombinasi aliskiren dengan ramipil dan irbesartan memberikan hasil penurunan tekanan darah yang lebih besar daripada terapi tunggal serta dapat ditoleransi dengan baik. Terapi kombinasi dengan aliskiren akan menetralisasi kompensasi berupa peningkatan PRA yang distimulasi oleh pemberian obat antihipertensi dan menjadi harapan untuk mengoptimalkan penghambatan terhadap RAAS [10]. Pada penderita hipertensi yang 
mengalami obesitas dengan BMI $\geq$ $30 \mathrm{~kg} / \mathrm{m}^{2}$ dan biasanya tidak memberikan respon yang memadai jika diberi terapi HCTZ 25mg, pemberian kombinasi aliskiren $150 \mathrm{mg}$ dan HCTZ $25 \mathrm{mg}$ akan menurunkan tekanan darah secara signifikan jika dibandingkan dengan penggunaan HCTZ secara tunggal [11].

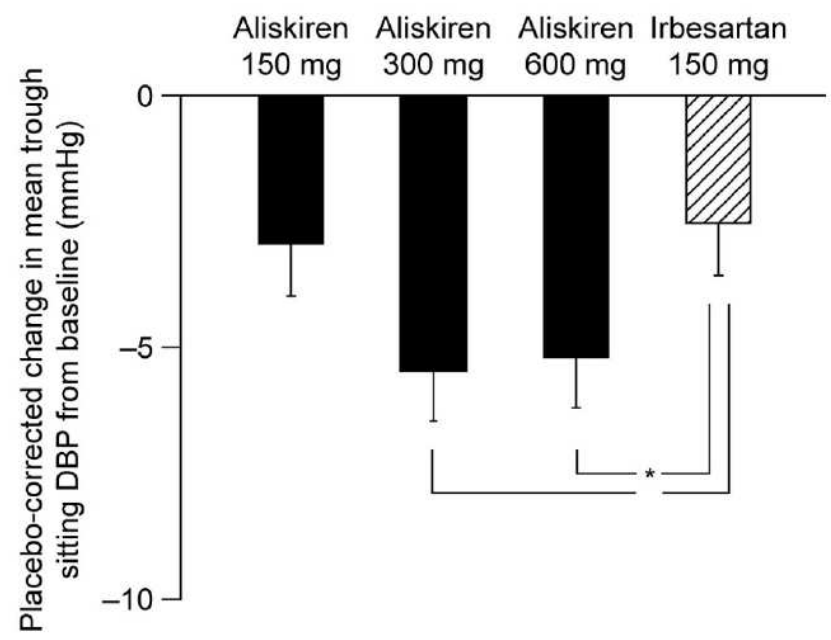

Gambar 3. Grafik penurunan tekanan darah setelah pemberian aliskiren dan irbesartan (5)

Tabel 2. Profil farmakokinetika aliskiren pada subyek orang jepang dan kaukasian (6)

\begin{tabular}{llllll}
\hline Study group & $\begin{array}{l}C_{\max } \\
\left(\mathrm{ng} \mathrm{ml}^{-1}\right)\end{array}$ & $t_{\max }(\mathrm{h})$ & $\begin{array}{l}\mathrm{AUC}_{0-72 \mathrm{~h}} \\
\left(\mathrm{ng} \mathrm{h} \mathrm{ml} \mathbf{l}^{-1}\right)\end{array}$ & $t_{1 / 2}(\mathrm{~h})$ & $\begin{array}{l}C_{\max } / \mathrm{AUC}_{0-72 \mathrm{~h}} \\
\left(\mathrm{~h}^{-1}\right)\end{array}$ \\
\hline Japanese $(n=19)$ & $215 \pm 122$ & $2.0(0.5-4.0)$ & $1387 \pm 615$ & $29.7 \pm 10.2$ & $0.16 \pm 0.06$ \\
Caucasian $(n=19)$ & $186 \pm 91$ & $2.0(0.5-6.0)$ & $1124 \pm 339$ & $32.0 \pm 6.6$ & $0.16 \pm 0.05$ \\
\hline
\end{tabular}

\section{KESIMPULAN}

Penelitian sebelumnya sudah mengindikasikan bahwa obat golongan renin inhibitor, termasuk aliskiren efektif sebagai antihipertensi dan dapat ditoleransi dengan baik, baik sebagai monoterapi maupun dikombinasi dengan obat lain. Berdasarkan penelitian yang sudah dilakukan terhadap aliskiren serta keberhasilan obat antihipertensi golongan ACEI dan ARB dalam menurunkan angka morbiditas dan mortalitas pada penderita hipertensi, maka sangat rasional jika diharapkan obat golongan renin inhibitor seperti aliskiren akan memberikan manfaat yang sama. Apakah manfaat tersebut sama, lebih besar atau justru lebih kecil daripada yang ditunjukkan oleh inhibitor RAAS yang lain, maka diperlukan penelitian lain yang panjang untuk mencari data pendukung.

\section{DAFTAR PUSTAKA}

1. Muller, D.N.; \& Luft, F.C. 2006, Direct Renin Inhibition with Aliskiren in Hypertension and Target Organ Damage, Clin. J. Am. Soc. of Nephrology, 1: 221-228

2. Saseen, J.J.; \& Carter, B.L. 2005, Hypertension, in DiPiro J.T., Pharmacotherapy a Pathophysiologic Approach, McGraw-Hill

3. Nafrialdi. 2007, Hipertensi, in Farmakologi dan Terapi, Departemen Farmakologi dan Terapi, Fakultas Kedokteran UI, Jakarta

4. Sukandar, E.Y.; Andrajati, R.; Sigit, S.i.; Adyana, I.K.; Setiadi, A.P.; \& Kusnandar. 2008, ISO Farmakoterapi, ISFI penerbitan. Jakarta 
5. Gradman, A.H.; Schmieder, R.E.; Lins, R.L.; Nussberger, J.; Chianh, Y.; \& Bedigian, M.P. 2005, Aliskiren, a Novel Orally Effective Renin Inhibitor, Provides Dose-dependent Antihypertensive Efficacy and Placebo-like Tolerability in Hypertensive Patients, Circulation, 111, 1012-1018

6. Vaidyanathan, S.; Jermany, J.; Yeh, C.; Bizot, M.N.; Camisasca, R. 2006, Aliskiren, a Novel Orally Effective Renin Inhibitor, Exhibits Similar Pharmacokinetics and Pharmacodinamics in Japanesse and Caucasian Subjects, British J. Clin. Pharmacology, 62:6, 690-698

7. Jan Danser, A.H.; Charney, A.; Feldman, D.L.; Nussbenger, J.; Kisner, N.; \& Hollenberg, N. 2008, The Renin Rise with Aliskiren, its Simply Stoichiometry, Hypertension, vol 51 e27-e28

8. Kushiro, T.; Itakura, H.; Yoshihisa, A.; Gatau, H.; Terdo, S.; \& Keefe, D.L. 2006, Aliskiren, a Novel oral renin Inhibitor, Provides dose dependent Effecacy and Placebo like Tolerability in Japanese Patients with
Hypertension, Hypertention Research, vol 29 no 997-1005

9. Oparil, S.; Yarrowa, S.; Patel, S.; Fang, S.; Yarrows, S.; Zhang, J.; \& Zlatan, A. 2009, Efficacy and Safety of Combined use of Aliskiren and Valsartan in patient with Hypertention; Randomised double Blind Trial, The Lancet, vol 370 p 221-229

10. O’brien, E.; Barton, J.; Nussberger, J.; Mulcany, D.; Jensen, C.; Dicker, P.; \& Stanton, A. 2007, Aliskiren Reduces Blood Pressure and Supresser Plasma Renin Activity in Combination with Thiazide Diuretics, an Angiotensin Converting Enzim Inhibitor or an Angiotensin Receptor Blocker, Hypertension, vol 49 p 276-284

11. Jordan, J.; Engeli, S.; Boye, S.W.; Le Broton, S.; \& Keefe, D.L. 2007, Direct Renin Inhibition With Aliskiren in Obese Patient with Arterial Hypertension, Hypertension, vol 49 p 10471055 